\title{
PENELITIAN PENDIDIKAN PADA MADRASAH
}

\begin{abstract}
Abdul Aziz ${ }^{1}$
Abstract

Educational research is crucial to develop sustainable educational program of Madrasah. Educational research provides important data to define the plan, evaluate the program, and promote enjoyable learning environment in Madrasah. Educational research in Madrasah still faces some problems such as limited budget, being reluctant to provide data and be research subject among principals and teachers of Madrasah. The researcher has to know research methodology both quantitative and qualitative method to conduct research activity in Madrasah. The valid and reliable findings in educational research are important for Madrasah to improve educational quality of Madrasah.
\end{abstract}

Keywords: educational research, madrasah

\section{A. Pendahuluan}

Pemerintah Indonesia dengan gigih dan berusaha keras tanpa henti dalam memajukan pendidikan Islam khusus memajukan mutu pendidikan di Madrasah sejak awal-awal kemerdekaan dengan dibentuknya Kementerian Agama Republik Indonesia.Berbagai usaha pembenahan dilakukan oleh pemerintah Indonesia demi peningkatan mutu pendidikan di Madrasah dengan peningkatan fasilitas pendidikan, peningkatan perpustakaan Madrasah dan peningkatan mutu guru. Namun, masih banyak permasalahan yang dihadapi Madrasah hingga kini dalam memajukan kiprahnya untuk membangun masyarakat Indonesia yang lebih maju dan mandiri. Ki Supriyoko (2004) menyatakan bahwa permasalahan yang dihadapi Madrasah menyangkut berbagai masalah antara lain persepsi masyarakat yang masih rendah terhadap Madrasah, pencapaian prestasi akademis yang belum bagus di banyak Madrasah, profesionalisme guru, dan kepemimpinan kepala Madrasah. Prestasi akademis yang belum memuaskan di kebanyakan Madrasah terlihat masih rendahnya nilai ujian akhie sekolah,walaupun beberapa Madrasah bisa menunjukkan prestasi akademis dan non akademis yang luar biasa baik tingkat daerah, nasional, dan bahkan internasional.Sampai

1 Dosen Fakultas Humaniora Universitas Islam Negeri Maulana Malik Ibrahim Malang Jl. Gajayana No. 50 Malang 65144 
saat ini masih banyak warga masyarakat yang enggan menyekolahkan putra-putrinya ke Madrasah, keengganan tersebut berawal dari persepsi mereka yang belum bagus terhadap kualitas proses belajar-mengajar di kebanyakan Madrasah. Kualitas guru-guru Madrasah juga masih rendah karena masih banyak guru Madrasah yang belum menyelesaikan pendidikannya pada jenjang sarjana dan banyak yang mengajar tidak sesuai bidangnya (Mahfud Djunaidi\&Muhammad Saifudin, 2005; Ahmad Khoirul Fata, 2006).Dan, masih banyak kepala Madrasah yang belum professional dalam mengelola Madrasah.Kebanyakan kepala Madrasah masih menerapkan pola kepemimpinan transaksional, kurang memberdayakan kemampuan guru, dan kurang melibatkan warga sekolah dan masyarakat dalam melaksanakan program pendidikan di Madrasah (Ki Supriyoko, 2004; Mahfud Djunaidi\&Muhammad Saifudin, 2005; Ahmad Khoirul Fata, 2006; Asmaun Sahlan, 2010).

Pemerintah Indonesia melalui Kementerian Agama Republik Indonesia selalu berusaha keras mengatasi berbagai permasalahan tersebut.Berbagai kerjasama dengan banyak pihak dan evaluasi untuk meningkatkan mutu pendidikan di Madrasah sudah banyak dilakukan oleh Kementerian Agama Republik Indonesia.Namun, masalah mutu pendidikan khususnya pendidikan dasar nampaknya bukan monopoli Madrasah saja. Penelitian oleh Dedi Supriadi (2004) mendapati bahwa hanya sekitar $10 \%$ dari keseluruhan lembaga pendidikan dasar di Indonesia yang dapat dikategorikan sebagai sekolah yang bermutu bagus.Berbagai usaha keras pemerintah Indonesia untuk memajukan mutu pendidikan Madrasah hendaknya dibarengi semangat kalangan akademis untuk melakukan penelitian pendidikan di Madrasah sehingga banyak informasi, langkah-langkah terobosan, dan strategi baru yang dihasilkan dari banyak kegiatan penelitian pendidikan demi kemajuan Madrasah itu sendiri. Tetapi, nampaknya masih banyak kendala dalam melaksanakan kegiatan penelitian pendidikan di Madrasah seperti yang pernah dialami oleh penulis sendiri dalam melaksanakan kegiatan tersebut.Berbagai masalah yang mengahmbat dalam pelaksanaan kegiatan penelitian pendidikan di Madrasah berkaitan dengan beberapa hal antara lain:

1. Pengelolaan data pendidikanyang belum bagus baik oleh Kantor Wilayah dan Kantor Kementerian Agama di berbagai kota/ kabupaten sehingga peneliti kesulitan untuk sekedar mengakses data-data umum seperti jumlah Madrasah yang terakreditasi A, 
jumlah guru yang bersertifikasi dan lain-lain;

2. Kebanyakan guru maupun kepala Madrasah enggan menjadi responden/subyek penelitian atau setidaknya enggan secara terbuka menyampaikan data-data pendidikan tentang proses belajar-mengajar dan manajemen pendidikan Madrasah sehingga hanya diperoleh data-data yang sangat terbatas untuk tujuan penelitian dan pengembangan Madrasah itu sendiri.

3. Banyak Madrasah utamanya Madrasah yang dikelola oleh pihak swasta/yayasan enggan untuk menjadi subyek penelitian dengan alasan untuk menjaga kerahasiaan pihak Madrasah dan yayasan dalam melaksanakan proses belajar-mengajar dan mengelola Madrasah.

Peneliti hendaknya memahami dengan baik tentang masalahmasalah tersebut dalam melaksanakan kegiatan pendidikan di Madrasah sehingga sedini mungkin dapat menjalin komunikasi dengan baik dengan pihak Madrasah serta pihak lain yang terkait demi terlaksananya kegiatan penelitian pendidikan di Madrasah dengan baik.Peneliti hendaknya juga selalu mengembangkan diri dengan pengetahuan tentang metode penelitian pendidikan berkenaan dengan jenis-jenis penelitian, rancangan penelitian dan instrumen penelitian sehingga dapat melaksanakan kegiatan penelitian dengan baik.

\section{B. Jenis-Jenis Penelitian Pendidikan}

Ada beberapa jenis penilitian yang umum dilaksanakan dalam dunia pendidikan untuk merencanakan, mengimplementasikan, mengembangkan, dan mengevaluasi program pendidikan dengan tujuan peningkatan mutu pendidikan di lembaga-lembaga pendidikan. Ary, Jacobs, and Razavieh (1979) mengklasifikasikan penelitian sebagai berikut:

1. Experimental research yakni peneliti memanipulasi, mengontrol, dan memberikan perlakuan terhadap kelompok control dan kelompok eksperimen untuk mendapatkan data penelitian.

2. Descriptive research yakni peneliti menafsirkan dan menjelaskan tentang fenomena; yang termasuk dalam penelitian ini adalah studi kasus, penelitian pengembangan, survey dan lain-lain. 
3. Historical research yakni ahli sejarah yang menguji kebenaran bukti-bukti sejarah untuk mengungkap peristiwa sejarah dan kronologi kejadian dalam sejarah.

Selanjutnya, Dash (2005) mengklasifikasikan penelitian sebagai berikut:

1. Positivism yakni pengetahuan dibangun dan dikembangkan oleh peneliti berdasarkan fakta-fakta yang diamati oleh peneliti. Dalam hal ini, peneliti melakukan penelitian eksperimen untuk membangun teori baru dan mengembangkan ilmu pengetahuan. Positvism menggunakan metode kuantitatif dalam melaksanakan kegiatan penelian.

2. Anti Positivism yakni peneliti mengamati dan menerjemahkan sebuah fenomena dari berbagai sudut pandang dari peneliti sehingga ilmu pengetahuan dibangun dan dikembangkan berdasarkan penafsiran dan pemahaman peneliti terhadap fenomena.Anti Positivism menggunakan metode kualitatif dalam melaksnakan kegiatan penelitian.

3. Critical Theory yakni peneliti melakukan berpikir kritis dan penelitian tindakan untuk mengkritisi sebuah fenomena, membangun dan mengembangkan strategi baru, dan memecahkan masalah terhadap fenomena yang terjadi saat ini. Penelitian yang termasuk dalam Critical Theory adalah penelitian tindakan kelas, penelitian evaluasi.

\section{Rancangan Penelitian}

Peneliti yang melaksanakan kegiatan penelitian pendidikan di Madrasah hendaknya membuat desain/rancangan penelitian dengan baik dan matang sehingga tujuan penelitian bisa tercapai dengan baik.Peneliti bisa menggunakan metode kuantitatif, metode kualitatif atau metode gabungan untuk mendapatkan data-data pendidikan sehingga bisa menghasilkan temuan penelitian yang dapat memberikan sumbangan positif untuk meningkatkan mutu pendidikan di Madrasah. Pada masa kini, para peneliti umumnya tidak hanya menggunakan metode tertentu dalam melaksanakan kegiatan penelitian pendidikan. Peneliti menggunakan umumnya mengkombinasikan metode kuantitatif dan metode kualitatif untuk memahami sebuah fenomena secara lebih mendalam dan komprehensif. 
Creswell (2003) menyatakan bahwa tidak ada satu metode penelitian yang lebih dari metode-metode penelitian yang lain, sehingga metode gabungan kuantitatif dan kualitatif dianggap lebih sesuai karena bisa mengkompensasi kelemahan-kelemahan di antara metode yang ada. Metode penelitian dalam penelitian social diklasifikasikan pada dua paradigm utama yakni metode kuantitatif dan metode kualitatif. Penelitian yang menggunakan metode kuantitatif disebut penelitian kuantitatif dan penelitian yang menggunak metode kualitatif disebut penelitian kualitatif(Newton, Newman\&DeMacro Jr., 2003).David Scott (1996)menyatakan bahwa penelitian eksperimen, penelitian ex post-facto, survey adalah penelitian kuantitatif; sedangkan etnografi dan studi kasus termasuk penelitian kualitatif.Selanjutnya, instrumen penelitian seperti wawancara terstruktur, kuesioner/angket, test kompetensi terstandar, dan test sikap sering digunakan untuk mendapatkan datadata kuantitatif; sedangkan wawancara bebas, observasi, dan catatan harian sering digunakan untuk mendapatkan data-data kualitatif. Libarkin dan Kurdziel (2002) menyatakan bahwa metode kualitatif adalah pendekatan yang tak terbatas terhadap sebuah fenomena; sedangkan metode kuantitatif berkaitan dengan problema-problema yang teridentifikasi dengan jalan menguji teori, menghitung angka, dan menganalisa data statistik (Creswell, 2003). Kemudian, David Scott (1996) menyatakan bahwa kedua metode kuantitatif dan kualitatif sebaiknya tidak digunakan secara terpisah tetapi saling melengkapi sehingga tidak menghasilkan konsepsi yang salah terhadap suatu permasalahan.

Vredenbregt(1978) menyatakan bahwa peneliti hendaknya mengkombinasikan metode kuantitatif dan kualitatif untuk memahami fenomena dan mengembangkan pengetahuan melalui uji hipotesis. Dash (2005) mengatakan bahwa metode kuantitatif dan kualitatif membantu peneliti mengembangkan pengetahuan dengan observasi, eksperimen, generalisasi, dan interpretasi terhadap fenomena.Wiersma (2000)menyatakan bahwa penelitian kuantitatif dan kualitatif memiliki karakteristik yang berbeda sesuai dengan tujuan penelitian.Penelitian kualitatif menfokuskan pada analisa deskriptif dengan cara berpikir dan menarik kesimpulan secara induktif yakni berawal dari data spesifik menuju kepada kesimpulan umum. Sedangkan, penelitian kuantitatif berkaitan dengan berpikir dan menarik kesimpulan secara deduktif yakni peneliti menguji teori berdasarkan data-data yang diperoleh. Peneliti yang menggunakan metode kuantitatif umumnya menekankan 
pada hasil penelitian, sedangkan peneliti yang menggunakan metode kualitatif umumnya menekankan pada proses penelitian (Wiersma, 2000).

Tashakkori dan Teddlie (1998) menyatakan bahwa penelitian yang mengkombinasikan metode kuantitatif dan kualitatif memberikan kesempatan kepada peneliti untuk mengimplementasikannya pada penelitian kasus tunggal dan penelitian multi kasus. Selanjutnya, Tashakkori dan Teddlie (1998) menyatakan bahwa penelitian yang mengkombinasikan metode kuantitatif dan kualitatif dapat menggabungkan kekuatan masing-masing metode dan saling mendukung untuk memperoleh data yang bermakna.Creswell (2003) mengatakan bahwa penelitian yang mengkombinasikan metode kuantitatif dan kualitatif dilaksanakan untuk mendapatkan data kuantitatif dan kualitatif demi tercapainya tujuan penelitian.Karena itulah banyak peneliti yang menggunakan metode gabungan dalam melaksanakan kegiatan penelitian agar dapat memahami fenomena secara lebih mendalam dan komprehensif.

Brannen (2005) menyatakan bahwa data kuantitatif dalam penelitian yang menggunakan metode gabungan meliputi data numerik yang diperoleh melalui kuesioner dan wawancara terstruktur; sedangkan data kualitatif adalah data deskriptif yang diperoleh melalui analisa dokumen, obeservasi, dan wawancara bebas.Dunning, Williams, Abonyi and Crooks (2008) menjelaskan bahwa penelitian yang semata menggunakan metode kuantitatif atau kualitatif hanya menghasilkan gambaran yang terbatas terhadap sebuah proses; sedangkan penelitian yang menggunakan metode gabungan bisa menyajikan perspektif multi dimensi terhadap fenomena sehingga bisa menghasilkan kebenaran, pengetahuan, dan pemahaman yang lebih komprehensif.

Creswell (2003), Gay, Mills dan Airasian (2009) menyatakan bahwa walaupun peneliti mempunyai keleluasaan untuk menentukan cara dalam menggunakan metode gabungan, namun hendaknya peneliti menggunakan enam variasi rancangan penelitian dengan metode gabungan dalam melaksanakan kegiatan penelitian sebagai berikut:

1. QUAN-Qual Model atau Sequential Explanatory Design yakni mengumpulkan dan menganalisa data kuantitatif terlebih dahulu kemudian diikuti pengumpulan dan analisa data kualitatif sebagai pendukung. Prioritas diberikan kepada data kuantitatif, sedangkan 
data kualitatif digunakan untuk mendukung dalam memahami temuan penelitian.

2. QUAL-Quan Model atau Sequential Exploratory Design yakni pengumpulan dan analisa data kualitatif terlebih dahulu kemudian diikuti pengumpulan dan analisa data kuantitatif. Prioritas diberikan kepada data kualitatif, sedangkan data kuantitatif digunakan untuk mendukung dalam memahami temuan penelitian.

3. Sequential Transformative Design yakni pengumpulan dan analisa data baik data kuantitatif dan kualitatif dilaksanakan bersamaan; sedangkan prioritas bisa diberikan kepada salah satunya. Dalam hal ini bisa $70 \%$ prioritas untuk data kuanitatif dan 30\% prioritas untuk data kualitatif atau sebalinya.

4. Concurrent Triangulation Design yakni dua metode digunakan secara terpisah untuk mengkonfirmasi dan menvalidasi hasil penelitian. Prioritas diberikan sama besar kepada metode kuantitatif dan kualitatif.

5. Concurrent Nested Design yakni dua metode digunakan secara terpisah untuk mengkonfirmasi dan menvalidasi hasil penelitian. Prioritas lebih ditekankan pada salah satu metode yakni $60 \%$ untuk metode kuantitatif dan $40 \%$ untuk metode kualitatif atau sebaliknya.

6. Concurrent Transformative Design yakni peneliti menggunakan perspektif tertentu dalam penelitian berdasarkan ideologinya, konsep kerja, dan masalahnya.

\section{Instrumen Penelitian}

Peneliti tentu menggunakan beberapa instrumen penelitian untuk mendapatkan data penelitian. Ada beberapa instrumen penelitian yang digunakan peneliti dalam melaksanakan kegiatan penelitian antara lain:

1. Wawancara

Lincoln and Guba (1985), Patton (1990), dan Burgess (1993) menyatakan bahwainterview atau wawancara mempunyai beberapa keuntungan dalam memahami masalah dengan baik. Pertama, dengan melakukan wawancara peneliti dapat memahamipengalaman masa lalu, 
situasi kehidupan masa kini, dan proyeksi masa depan dari responden. Kedua, wawancara itu sifatnya fleksibel dan mendalam sehingga peneliti dapat memperoleh data penelitian yang lebih kaya dan variatif.Ketiga, peneliti dapat memperoleh informasi yang signifikan karena responden dapat mengungkapkan pikirannya secara lebih terbuka (Cheah Lee Hwa, 2008).Koul (1984) menyatakan bahwa wawancara yang terstruktur dapat memperoleh data yang lebih spesifik terhadap suatu kejadian; dan wawancara yang tak terstruktur bisa membuat responden lebih bebas dalam mengungkapkan pendapatnya.

\section{Observasi}

Rummel (1964) menyatakan bahwa observasi perlu dilakukan untuk melihat situasi kehidupan sekolah yang sebenarnya. Kemudian, Koul (1964) menyatakan bahwa observasi harus direncanakan dengan baik berkenaan dengan hal-hal sebagai berikut: kegiatan yang diobservasi, situasi yang sebenarnya dari kelompok yang diobservasi, observasi individual dalam kelompok, jangka waktu observasi, dan menentukan peralatan yang digunakan dalam melakukan observasi. Patton (1990) menyatakan bahwa pelaku obesrvasi hanyalah sebagai penonton atau non partisipan dalam kegiatan observasi (Cheah Lee Hwa, 2008). Dalam melakukan kegiatan observasi, peneliti bisa membuat catatan dari apaapa yang diobservasi yakni kehidupan sekolah yang sebenarnya, proses belajar-mengajar dan lain-lain. Bodgan dan Biklan (1992) menjelaskan bahwa catatan lapangan adalah catatan peneliti tentang apa yang dilihat, didengar, dialami, dan diperkirakan oleh peneliti selama melaksanakan kegiatan penelitian (Cheah Lee Hwa, 2008).

\section{Dokumentasi}

Rummel (1964) menjelaskan bahwa dokumentasi meliputi beberapa hal sebagai berikut: a) sumber-sumber faktual seperti katalog lembaga, catatan peristiwa, catatan pertemuan,dokumen-dokumen resmi dan lain-lain b) pelaksanaan program pendidikan seperti silabi, kurikulum, program harian guru, buku teks dan lain-lain c) analisa hasil belajar siswa seperti buku rapor, buku perkembangan siswa dan lain-lain. Dokumentasi membantu peneliti memahami masalah penelitian dan masalah pendidikan dengan lebih baik. 


\section{4. $\quad$ Test}

Ary, Jacobs, dan Razavieh (1979) menyatakan bahwa test adalah instrumen pengukuran dalam penelitian pendidikan. Test adalah seperangkat soal/pertanyaan yang harus dijawab oleh individu yang dapat diukur dengan angka (Ary, Jacobs,dan Razavieh, 1979). Test yang baik adalah test yang memenuhi reliabilitas, validitas, dan obyektifitas (Ary, Jacobs,dan Razavieh, 1979).

\section{Kuesioner}

Kuesioner atau angket adalah instrumen penelitian untuk memperoleh informasi tentang fakta, kepercayaan, perasaan, kecendrungan dan lainlain (Ary, Jacobs,dan Razavieh, 1979).Kuesioner adalah seperangkat pertanyaan tertulis yang diberikan kepada responden untuk memperoleh data penelitian. Kuesioner lebih efisien dan praktis dibandingkan dengan wawancara (Ary, Jacobs,dan Razavieh, 1979). Biasanya, kuesioner dirancang/didesain menurut skala Likert lima poin dari poin 1 sampai dengan poin 5 .

\section{E. Kesimpulan}

Penelitian pendidikan sangat penting dilaksanakan di Madrasah dan sekolah-sekolah Islam yang lain karena penelitian pendidikan dapat memberikan informasi dan strategi baru untuk membangun Madrasah dalam meningkatkan mutu pendidikan sehingga bisa bertahan dan bahkan semakin unggul pada era yang penuh persaingan yang tinggi ini. Kantor Wilayah dan Kantor Kementerian Agama di kabupaten/kota hendaknya lebih meningkatkan manajemen data tentang pendidikan Madrasah dan terbuka dalam menyajikan data pendidikan Madrasah sehingga memudahkan peneliti melakukan penelitian pendidikan di Madrasah yang hasil kajian bisa meningkatkan mutu pendidikan Madrasah.Peneliti pendidikan tentu saja harus memahami kaidah penelitian sehingga menghasilkan temuan-temuan baru yang terpercaya, valid, dan obyektif. 
Abdul Aziz - Penelitian Pendidikan pada Madrasah

\section{DAFTAR PUSTAKA}

Ahmad Gunaryo.(2001). Madrasah di Era Otonomi Daerah in Potret Madrasah Dalam Media Massa, Kemenag RI(2006), Jakarta.

Ahmad Khoirul Fata.(2006). Anak Tiri Itu Bernama Madrasah in Potret Madrasah Dalam Media Massa, Kemenag RI (2006), Jakarta.

Ahmad Sholeh.(2009) Pemberdayaan Pendidikan Dasar, Jurnal Madrasah Volume 1 No. 2 Januari-Juni 2009 ISSN 1979-5599209221.

Arikunto Suharsimi.(1983). Prosedur Penelitian: Suatu Pendekatan Praktik, Jakarta, PT Bina Aksara.

Ary, D., Jacobs, L.C.\& Razavieh, A.(1979). Introduction to Research in Education, New York, Holt, Rinehart and Winston.

Asmaun Sahlan.(2010). Manajemen Pendidikan Islam, Jogjakarta, ArRuzz Media.

Brannen,J. (2005). Mixing Methods: The Entry of Qualitative adn Quantitative Approaches into the Research Process, International Jornal of Sociological Methodology,8,173-184.

Cheah Lee Hwa.(2008).The Impact of Principal's Transformational Democratic Leadership Style on Teachers' Job Satisfaction and Commitment, Universiti Sains Malaysia, Unpublished Ph.D. Thesis.

Choirul Fuad, Imran Siregar, Nunu Ahmad\&Lisadiyah.(2006) Potret Madrasah Dalam Media Massa, Jakarta, Pusat Penelitian Dan Pengembangan Pendidikan Agama Dan Keagamaan Kementerian Agama Republik Indonesia.

Creswell, J. (2003). Research Design: Qualitative, Quantitative, and Mixed Methods Approaches(2nd edition), Thousand Oaks, CA:Sage.

Darren, G. \& Mallery, P. (2003), SPSS for Windows Step by Step: A Guide and Reference 11.0 Update, Boston, Allyn and Bacon.

Dedi Supriadi.(2004). Membangun Bangsa Melalui Pendidikan edited by Rohmat Mulyana, Bandung, Remaja Rosdakarya. 
Dunning,H., Williams, A., Abonyi,S., \& Crooks, V. (2008). A Mixed Method Approach to Quality of Life Research: a Case Study Approach, Social Indicator Research, 85, 145-158.

Field, A. (2005). Discovering Statistics Using SPSS, Second Edition, SAGE, London.

Gay, L., Mills, G.E., \& Airasian, P. .(2009). Educational Research: Competencies for Analysis and Applications, London, Pearson.

Hair, J.F., Black W.C., Babin, B.J., Anderson, R.E., \& Tatham, R.L. (2006).Multivariate data analysis. $\left(6^{\text {th }} \mathrm{Ed}\right)$. New Jersey: Pearson Education International.

Hair, J.F., Black W.C., Babin, B.J., Anderson, R.E., \& Tatham, R.L. (1998).Multivariate data analysis. New Jersey: Pearson Education International.

Krejcie, R. V., \& Morgan, D. W. (1970). Determining sample size for research activities.Educational and Psychological Measurement (30), 607-610.

McAshan, H.H.(1963). Elements of Educational Research, New York, McGraw-Hill Book Company, Inc.

Moore, G.W.(1983). Developing and Evaluating Educational Research, Boston and Toronto, Little, Brown and Company.

Neuman, W.L.(2000).Social Research Methods, Qualitative and Quantitative Approaches, Boston, Allyn and Bacon.

Newton, I.R., Newman, C., and DeMacro Jr.,G.M.(2003). A Typology of Research Process and Its Relationship to Mixed Methods in A. Tashakori and C. Tedlie, Handbook of Mixed Methods in Social and Behavior Research(167-188), Thousand Oaks, Sage Publications.

Nisbet, J.D. and Entwistle, N.J.(1970). Educational Research Method, London, University of London Press Ltd.

Nunally, J.C.(1978). Psychometric Theory (3ed), New Yok, Mc GrawHill.

Sax, G.(1979).Foundations of Educational Research, New Jersey, PrenticeHall, Inc. 
Scott, D.\& Usher, R.(1996). Understanding Educational Research, London and New York, Routledge.

Sekaran, Uma.(2000). Research Methods for Business: A Skill-Building Approach. New York, John Wiley and Sons, Inc.

Tabachnick, B. G., \&Fidell, L.S. (2007).Using multivariate statistics (5 ed.). New York: Pearson and Bacon.

Tashakori, A.(1998). Mixed Methodology: Combining Qualitative and Quantitative Approaches, Thousand Oaks, CA,Sage.

Vredenbregt, J.(1978).Metode dan Teknik Penelitian Masyarakat, Jakarta, Gramedia.

\section{Electronic Source:}

www.celt.mmu.ac.uk accessed on February 25, 2011

www.honolulu.hawai.edu accessed on January 18, 2010 